\title{
The modern touch: interior design and modernisation in post-independence Singapore
}

\author{
Jane M Jacobs \\ Institute of Geography, School of GeoSciences, University of Edinburgh, Drummond Street, \\ Edinburgh EH8 9XP, Scotland; e-mail: jane.jacobs@ed.ac.uk
}

\section{Stephen Cairns}

Department of Architecture, School of Arts, Culture and Environment, University of Edinburgh, 20 Chambers Street, Edinburgh EH1 1JZ, Scotland; e-mail: stephen.cairns@ed.ac.uk Received 3 April 2006; in revised form 3 October 2006; published online 11 June 2007

\begin{abstract}
The authors take as their focus the advice on interior design and decoration that Singapore's Housing Development Board (HDB) distributed to residents as part of its programme of universal housing provision. Through a series of regular articles appearing in the HDB publication Our Home (1972 - 1989), readers were presented with stories that showed how selected HDB residents decorated their newly acquired highrise flats. The authors detail the relationship between this design advice and the commitment to modernist design principles, the self-conscious pragmatism of the HDB, and the reliance on a limited market logic ('homeownership'). The HDB's vision of the benefit of its highrise housing programme was, from the outset, complexly entangled with cultivating individual investments in the home by way of interior design and decoration practices. The paper contributes not only to the specific story of Singaporean housing, but also to wider scholarship on modernism, the everyday practices of interior design, and housing consumption.
\end{abstract}

\section{Introduction}

From its beginnings in 1960, Singapore's Housing Development Board (HDB) has been the main provider of housing for Singaporeans and nowadays accommodates well over $85 \%$ of the population in 'owned' (long-term leasehold) flats. Constrained by land shortages, committed to the pragmatics of efficient delivery, and no doubt influenced by global trends in mass-housing provision, it enthusiastically adopted the modernist highrise as the architectural type for its post-independence programme of universal housing provision. The HDB has routinely reflected with pride on the part which it, and its housing programme, have played in the making of modern Singapore. For example, the HDB's main office, dubbed 'The Hub', has always boasted a small museum space showcasing the institution's achievements. In the HDB's current headquarters, the museum is part of an extensive display space called 'The Gallery' which uses a series of 'before and after' interior recreations to tell the story of the HDB's role in providing 'homes for the people'. Visitors are led past 'slum', 'squatter', and 'kampung' interiors, on to the modern interiors of the 1960s highrises, and then to contemporary innovations like the entirely prefabricated 'plug-on' bathroom. The curatorial sensibility of this display lays somewhere between that of the museum diorama and the show home and, indeed, visitors can move seamlessly from the interior recreations of the museum space to a series of full-scale, fully decorated interior layouts of HDB flats currently on offer to prospective buyers. ${ }^{(1)}$ The centrality of these displays at The Hub hint at the special role which the interior and interior decoration have played in the housing-provision story of Singapore. 
In this paper we argue that the home interior lay at the heart of a finely calibrated relationship in which state-based processes of collective consumption combined with emergent patterns of individual consumption in the cultivation of a modern, postindependence Singaporean nation and citizenry. We focus specifically on previously undocumented advice given on home decoration by way of a series of articles appearing in the HDB-produced magazine, Our Home, which was distributed free to all HDB tenants between 1972 and 1989 - a period covering the Third to Sixth Building Programmes. These articles make it possible to see past the often uniform exteriors of these modernist highrises and glimpse varied outcomes of interior styling. In these emergent Singaporean interiors amateur interpretations of interior style mixed with idealised notions of modern decor, freedoms of expression jostled with state regulatory frameworks, and efforts to encourage domestic creativity rubbed against the economic benefits and costs of expanding home-related consumption.

We appreciate that our focus on a subset of official housing discourse in Singapore runs counter to the ethnographic emphasis currently shaping, among other things, studies of the home (see, as examples, Attfield, 1999; Buchli, 1999; Clarke, 2001; Llewellyn, 2004; Madigan and Munro, 1996; Miller, 1988; 2001a; Sparke, 2004; ToliaKelly, 2004). This is not based on a judgment about the relative merits of studies of discourse versus studies of practice: rather, it is born out of both practical and theoretical concerns. From a practical point of view, the textual archive is essential to historical work on the interior. Decorative schemes (along with residents) change frequently such that they are relatively ephemeral artifacts. Our retrospective accounting of them depends, in large part, upon existing records (Sparke, 2004). For example, accessing what interiors might have looked like in post-independence Singapore is greatly assisted by the interior decor articles which appeared in Our Home, for they feature images of the now largely vanished interiors of actual HDB residents. They also feature residents' explanations of their choices and constraints, offering a valuable insight into everyday practices of interior decoration. Admittedly, the homes and residents featured in Our Home would have conformed to official ideals for HDB interiors, such that these residents and their flats could operate illustratively. But while this filter creates a limit in terms of these articles offering a window onto the full range of homemaking practices of the time, it also brings clearly into view the recursive relationship between the 'ideal' (discursive) home and the 'real' (practised) home (see Chapman and Hockey, 1999; Sparke, 2004, van Caudenberg and Heynen, 2004). This leads us to the theoretical value of attending to a representational field such as that contained in Our Home. Muthesius (2005) has shown that the emergence in the 19 th century of the private domestic interior as a discrete site and conceptual category was, from the very outset, accompanied by a range of representational media such as the interior design magazine and the shop window 'stage set' display. Understanding "the actual design and consumption of interiors" is always in conversation with "the representation of design in mass-mediated form" (Aynsley and Berry, 2005, page 1). Following Miller (2001a), we wish to press this relational association further by showing how the house itself is part of a process of mediation whereby a household encounters wider society, including ideas about how a home interior should look, how one can be modern, or, even, how one can be Singaporean. As we show, the look of the emergent Singaporean interior was not about styles that belonged to some preexisting, determining sphere, like that of 'modernist design'; nor simply to structures external or prior to the act of homemaking (like the prescriptions of a state-based housing programme); nor did it reside solely in the "expressive" home-decorating efforts of residents, even when done as do-it-yourself (Miller, 2001a, page 10). Singaporean interiors, like home interiors generally, emerged out of a complex and often contradictory relationship 
between decorative and consumption practices and ideals, orders, and grammars that resided both in the site of the home and elsewhere-on design drawing boards, in bureaucracies, in magazines, in commercial premises, in a resident's imaginative and practical world, in the very colour of paint, texture of walls, and pieces of furniture (be they newly acquired or handed down) (Sorensen, 2002, page 24). For example, in relation to "the proliferation of home decoration and the popularization of design" in Britain, Clarke (2001, page 26) acknowledges that the house form and normative ideas of style "cast a shadow" over individual interior decoration decisions and efforts. But, as an alternate to this "shadow", she does not simply propose that analysis turn to an expressive counterstyling held surely and solely in the hands of the resident. Rather, Clarke (page 42) reveals how the relationship between "ideal" and "actual" worlds of home decorating is embedded in a complex process of mediation whereby a resident's "internalization" of "ideal home" design prescriptions entangle with his or her own "projection" of "ideal home" design fantasies and aspirations.

\section{Where is the modern interior?}

The special role played by the HDB's notions of domestic interior in the modernisation of post-independence Singapore echoes the central place the interior held in early theorisations of modernity more generally. For example, Benjamin (1999) saw the ornamented 19th-century domestic interior as an emblematic space of modernity, against which the ideals and aesthetics of modernism formed. In what follows we take as a starting point Benjamin's reflections on the relationship between the domestic interior, modernity, and modernism. In doing so we do not wish to imply that a modernity (including architectural modernism) that originated in Europe was simply applied to, or poorly imitated in, Singapore. To do so would be to entrap Singaporean modernisation and modernism within a developmentalist model (Robinson, 2006). But we do not wish to dislodge modernism entirely from the specificities of its production such that its 'international' aspirations outrank the situated nature of its making (and remaking). The stylistic and ideological shape of the modernism in which Singapore invested in so enthusiastically through its housing programme was, in the first instance, generated in Europe (although see Vogt, 1998). The post-independence Singaporean interior, although made and lived within the context of quite localised agendas and aspirations and, as we shall see, reshaping modernism quite dramatically, was at the same time inevitably in conversation with this other history and geography.

The 19th-century domestic interior was inextricably linked to the expansion and intensification of urban experience under industrialisation. The industrial city not only delivered new freedoms but also previously unknown levels of fragmentation and stimulation (Simmel, 1950). In this context, "living space became distinguished from the space of work" as never before, offering a refuge from the busy-ness outside (Benjamin, 1973, page 167). With this, the consumption of domestic goods offered new opportunities for individual expression and identification (Benjamin, 1999, page 227). The home and the commodities within it became part of a contradictory arrangement of defensive display. On the one hand, furnishings, finishings, and ornaments were increasingly asked to carry meaning as objects of self-expression. On the other, interior styling was such that domestic objects were secreted away through the use of "[c]overlets and antimacassars, cases and containers" "étuis, dust covers and sheaths" (Benjamin, 1999, pages 9 and 226). This "fortified" interior depended upon a nested spatiality wherein one space-be it a room, a cabinet, a receptacle, a pouch, or pocket-always seemed to contain another, in a refining and miniaturising sequence. Bourgeois homemakers fabricated scenes, moods, and atmospheres of the "far away and the long ago" such that the living room itself was "a box in the theater of the world" 
(pages 8-9). Here the "self-satisfied burgher" could create interior atmospheres and through them "know something of the feeling that the next room might have witnessed the coronation of Charlemagne ... the assassination of Henri VI, the signing of the Treaty of Verdun ... the wedding of Otto and Theophano" (page 216).

In this domestic scene the bourgeois urban subject and the consumer object were entangled in an evermore intricate coproduction of selfhood. That intimacy left its trace in the very fabric of the home, often enough velour or plush fabrics, which readily "preserve[d] the imprint of all contact" (Benjamin, 1999, page 9). Such surfaces acted as clues to, and cues for, the pattern of daily life. In Benjamin's view, the 19th-century dwelling operated like a shell or a compass case in which shelter and the occupant were so "moulded" to one another that they were mutually defining (page 220). Benjamin was critical of this fit, which he thought produced a "nihilistic cosiness", a dream-like "satanic calm" from which one might never stir (page 216, see also van Herck, 2005). Although these interior worlds operated quite literally as escapes and retreats from the capitalist competition animating the industrial city, their production depended upon new practices of consumption. As Holland (1988, page 412) suggests, the home became the "altar" of a new private religion of industrial capitalism, "and its idol ... [was] the fetish called 'Commodity'."

Benjamin's critique of this commodified and phantasmagorical mode of dwelling, drew upon modernist models of living, as articulated in Le Corbusier's Urbanisme (1924) (translated as The City of Tomorrow and Its Planning). The transparency, airiness, and openness of Le Corbusier's vision "put an end to dwelling in the old sense" (Benjamin, 1999, page 221). Modern architecture had little interest in sustaining the interior as a personal retreat serving individual expression. The smoothness of materials used in modern architecture and the flatness of its forms were inimical to the traces of its inhabitants and sought to hide nothing. "Glass", as Benjamin notes, "is such a hard and flat material that nothing settles on it ... It is above all the enemy of secrets. It is the enemy of possessions" (cited by Reed, 1996, page 10). Ornament too was a specific bother for the modern style. Essays like "Ornament and crime" (Loos, 1997[1908]) laid the grounds for subsequent modernist thinkers to designate ornament as undesirable, not only on the basis of aesthetics, but also because it was associated with undesirable 'primitive', or 'feudal', social orders. As Lubbock (1995, page 301) has noted, the advocates of the modern style "claimed that good modern design and civilisation were one and the same."

This apparent indifference to the traces of domestic life is perhaps most compellingly represented by the dogma of whiteness, now a "given" of modernism's aesthetic (Young, 2004, page 13). Architectural historian Mark Wigley (1995) has shown that by the late 1920s the identity of modern architecture came to be "located in its white surfaces", so much so that the idea that modern architecture is white was accepted internationally (page xiv). For Le Corbusier, and other modernists, white was not simply a colour scheme: it was an embodiment of the ethical, political, and moral substance of modernism. This is most clearly stated in Le Corbusier's 1925 book L'art décoratif d'aujourd'hui (translated as The Decorative Art of Today 1987), in which he examined the objects of contemporary everyday life and condemned those that had ornate decoration. He read such decoration as a mask that alienates the object from its user, creating a nostalgia that disguises its true origin and function. In his repudiation of the visual confusion and alienation which he believed ornamental surfaces promoted, Le Corbusier advocated the whitewashing of architecture-both inside and out. For Le Corbusier (1987 [1925], page 190) the white surface functioned like "an x-ray of beauty" and "eye of truth" disclosing new aesthetic potentials of unadorned, mass-produced, functional objects of modern metropolitan life. 
Modernism's journey from the drawing boards and manuscripts of designers to the interiors of 20th-century homemakers was by way of a range of representational media, themselves elaborations of the media that accompanied the emergent 19th-century domestic interior. The reproduction 'ideal home' or 'show home' was significant in this regard, playing an important part in the dissemination of the ideal of the design and living principles of modernism [Chapman (1999), Chapman and Hockey (1999); Clarke (2001); Woodham (2004), and specifically in relation to Singapore, Baydar Nalbantoglu (1997)]. Much recent research has shown that the coherent modernist visions of drawing boards, magazines, and show homes did not comprehensively replace earlier configurations of domestic space or preexisting home-styling habits. Such modernist visions always jostled with existing practices and preferences, coming to be reshaped by distinctive national contexts, specific state and private sector agencies, existing housing fabrics, as well as residents' inherited objects, persistent nostalgias, and existing grammars for domestic living (cf Attfield, 1989; 1999; Boudon, 1979; Buchli, 1999; Chua, 1997; Gullestad, 1992; Llewellyn, 2004; Miller, 1988; 2001b). It is not our intention to recount in detail the growing research that has accounted for how modernist domestic architectures have been lived. However, we would like to note some distinctive analytical threads in relation to the work on lived modernism. First, there is a tendency always to position modernism, at least in the first instance, as belonging to visions and structures external to those of the householders themselves. For example, in the work of Gullestad (1992, page 77) ideas of modernism belong in the hands of planning and architectural professionals who are responsible for what she refers to as "the almost mute" outsides of houses. Domestic modernism is further caricatured as inserting itself into the daily lives of householders either by stealth, through the constraints imposed by modernist built fabric, or by force, in the case of state-provided modernism. For example, Buchli's (1999) study of architectural modernism in the Soviet Union shows how the "domestic front" became a "locus of battle" against petit bourgeois values, such that homemaking and taste became legitimate concerns for the state (page 41), justifying interventions in everything from levels of light to the necessity for "de-artifactualisation" (pages 140-149). Such interpretations tend to externalise the origins of the idealised domestic modern such that the reality of a lived modern must always be a matter of internal (resident) reaction: 'accommodation', 'interpretation', 'adaptation', 'adjustment', 'appropriation', 'resistance'. As stated in our opening sections, we would wish to assume a more complicated relationality between the agents that make the modern interior, such that the home is more properly understood as "both the source and the setting of mobility and change" (Miller, 2001a, page 4) - a multimedia event that entangles design ideals, the materiality of things, rules and regulations, with individual and collective effort.

\section{Turning houses into homes in post-independence Singapore}

Much has been written about the unique public housing provision programme of postindependence Singapore, and in what follows we confine our attention to those aspects of the existing scholarship that bear upon the place of the interior and the role of interior styling. The structure and style of housing provision in Singapore animated the interior of flats in a very specific way, such that homemaking became not simply something that residents did within the freedom of their own home but a matter of state concern and effort. The HDB began its task of 'housing a nation' as a fledgling postindependence bureaucracy, having assumed the responsibility of housing provision from the colonial Singapore Improvement Trust. The post-independence Singaporean state invested heavily in highrise modernist housing, but did so for reasons that went far beyond a social welfare commitment to provide "decent shelter" (Castells et al, 1990, page 303). 
Housing provision was a key mechanism in the making of modern Singapore-politically, culturally, and economically. Chua (1997) has observed that the commitment to universal provision meant that housing came to operate as a covenant between people and government, with continually upgraded housing offered in exchange for political support for the People's Action Party (PAP) (see also Lim, 1989). Housing also provided a tool for the cultural integration of the nation. By applying specific formulas of multiethnic mixing in blocks and estates, the HDB provided a crucial mechanism for engineering a well-integrated, multiethnic Singapore (Lai, 1995). Housing became an intrinsic part of this emergent 'developmental state': lowering costs of living, developing urban infrastructure, directing capital formation (through compulsory savings), and providing employment opportunities (Castells et al, 1990).

The prioritising of development was a hallmark of post-independence Singapore and, as Kong (2000, page 411) notes, this was motorised by a pragmatic reasoning justified by the uncertainty surrounding post-independence Singapore's chances of survival as a viable social, economic, and political entity (see also Castells et al, 1990, page 190). During, this period the state cultivated a continual sense of crisis and urgency in relation to which it could exercise exceptional powers. One such intervention was the decommodification of land, which allowed its compulsory acquisition for the purpose of any development deemed to be in the national interest (Perry et al, 1997, page 6, see also Chua, 1997). Clancey (2004), for example, has noted that Singapore's post-independence housing programme was justified explicitly by the diagnosis of a 'housing emergency'. Landmark events, such as the 1961 fire in the 'squatter village' of Bukit Ho Swee which left hundreds homeless, were used by the state to underline both the 'necessity' of housing modernisation, as well as the ability to tackle the problem quickly and efficiently (Clancey, 2004, page 45; see also Chua, 1989). Singapore's 'housing emergency' was at the same time linked to official adjudications that existing housing (be it kampung, shop-house, or squatter settlement) was inappropriate because it was not modern, falling short of standards of sanitation, exhibiting overcrowding, forcing 'inappropriate' activities onto the street, or harbouring politically subversive or illegal activities (see Kong and Yeoh, 1994). As such, rehousing was fundamentally conceived of by the state as a developmental journey: from 'back then' to 'right now', from 'uncivilised' to 'civilised', from 'premodern' to 'modern'.

The HDB's wholehearted embracing of highrise modernism as the architectural style for its housing programme was also justified pragmatically, rather than aesthetically or ideologically (Kwek, 2004). As Lui Thai Ker (then Executive Officer) reflected in a 25th anniversary publication, the commitment to the highrise was "not intended to show off economic and technological capabilities" - there was "simply no other choice" (Lui, 1985, page 8). Despite the HDB already being aware of what they termed their "inherent disadvantages" and "handicaps" (Tan et al, 1985, page 56), and admitting the "belief" held by "some sociologists" that highrises contribute to a "sense of isolation", practical reasoning nonetheless led inexorably upward:

"The HDB has taken from the start a realistic and pragmatic stand by deciding that, in order to house every citizen decently, the residential density must be high. In order to sustain a high standard of living conditions, the dwelling units must be as large as the applicants can afford. To meet the criteria of high-density and large flats, the buildings have to be high-rise" (Lui, 1985, page 8).

In Housing a Nation (Lui, 1985) the official narrative makes clear the fine-grained effort the HDB put into overcoming problems that were already evident in the highrises of Europe and North America. This effort was manifest in rules and regulations about how residents should live in their homes and communities, systems of housing allocation, as well as a range of educational programmes that cultivated specific types 
of behaviour and values. It is perhaps unsurprising that scholarly and populist commentators routinely describe Singapore as 'authoritarian' in style. Certainly, Castells et al (1990, page 8) see the collective consumption of housing as a key mechanism of "social control in the management of the economy and of the society". But perhaps it is Wee's (2001, page 987) characterisation of Singapore's mode of rule as "disciplinary modernisation" that best approximates what was operating during the immediate post-independence years. For, as Wee observes, during this time the state sought not to be unilaterally authoritarian, but to "re-tool the subjectivities of its citizenry in the name of a modernist ... utopianism" (pages 987 and 999).

The practical complexity of Singapore's development style is explicitly expressed through one unique feature of Singapore's 'public' housing story, this being the Home Ownership for the People Scheme, established in 1964. The scheme augmented the commitment to universal housing provision with a vision for a "property-owning democracy" and did so by allowing all HDB residents the opportunity to "buy" (on long-term 99 year, leaseholds) their flats (HDB Annual Report 1964). As Chua (1997, page 3) notes, in most advanced capitalist contexts where housing provision is dominated by a private property system, public housing operates as a "contingent response to market failures in providing affordable housing for all." As such, it is structurally residualised and marginalised within that wider market hegemony. The Singaporean system of housing provision deviates from this structure in significant ways, such that public provision proceeded in unison with what Chua (1997, page 3) called the "disciplinary constraints of the market". The Singaporean homeownership scheme was heavily subsidised by the state, both directly and indirectly. The decommodification of land for the purpose of compulsory acquisition kept land values out of the equation determining house prices until 1987. Indeed, as it enjoyed a virtual monopoly on supply of housing in Singapore, the HDB was also able to fix tenure eligibility and prices of flats according to factors of its own determining (mainly the state of the economy, and levels of affordability). Initial take-up of the scheme was low, so in 1968 a new initiative was introduced which allowed residents to use a proportion of their compulsorily acquired savings, held in the government's Central Provident Fund (CPF) (see Lin and Tyabji, 1991; Tan, 1998). HDB tenants and others wishing to enter HDB housing, could not only pay their monthly mortgage through their CPF, but also call upon it for the initial $20 \%$ downpayment. In the year following the opening of the CPF monies to aspirant homeowners, applications to buy HDB flats tripled from 2384 to 7407, while applicants to rent almost halved (Castells et al, 1990, page 233). By 1970 some 63\% of all public housing applicants applied to buy (Chua, 1997, page 23) and by $197961 \%$ of the 337247 units of the HDB were owner-occupied (Castells et al, 1990, page 236).

This system of "public home ownership" (Tu, 1999, page 100) is especially relevant to understanding the post-independence Singapore interior, and the role of design in its making. Although there were economic and political aspirations associated with encouraging homeownership, this strategy also protected and enhanced existing state investment in housing. It was assumed that homeownership would encourage residents to look after their homes: "they have an investment in it and they look after it", said the Senior Principal Architect of the HDB in the Straits Times in 1984 (quoted by Castells et al, 1990, page 231). Furthermore, from 1971 onwards, limited opportunities were opened up for owners to sell on their homes to others eligible for public housing, at a price agreed upon between seller and buyer. Capital gains acquired through the sale could be used to buy into a better flat or, if the vendor elected to downgrade, be realised as profit. Although sales of this sort could only be made once (thus preventing the public stock being used for speculation), it did convert the HDB flat into an "investment good" from the point of view of residents (Chua, 1997, page 24). 
With the introduction of the homeownership scheme new expectations emerged around the type and standard of flats provided, and one of the HDB's most demanding administrative preoccupations became maintenance of the asset value of public housing flats (Chua, 2003, page 770). In this context there was a need to produce flats with a 'value potential' in excess of that attached to the idea of 'emergency shelter'. The supply emphasis moved away from one-room emergency flats, to larger and more varied layouts. In 1966 the Design and Research Unit was established by the HDB specifically to study and advise on ways to improve the standard of flats, not only to meet residents' housing needs better, but also to ensure their marketability. During the 1970s a number of improved flat designs were developed, including the five-room 'standard'; 'new' flats with larger rooms and improved ventilation and fixtures; and the spacious 'Model A' flats with $10 \%-20 \%$ more floor area (Castells et al, 1990, page 237). By 1979 the HDB was in the process of converting all one-room 'emergency' flats-knocking together units to create three-room flats - and had introduced the first generation of 'executive' flats.

\section{Entering the Singapore interior}

In this model of housing provision the responsibility for the finishes and look of interiors had a specific structure. Apart from selected blocks, all HDB flats were built with the expectation that residents would finish and furnish the interior of the flat themselves. From the 1970s, when the homeownership scheme was introduced, the large majority of flats had only basic fixtures and finishes provided by the HDB in order to ensure minimal standards of comfort and sanitation (sinks and toilet) and to protect the main structure from water damage (tiling in the wet areas). Indeed, as homeownership took off there was increasing dissatisfaction with the basic HDB finishes. Residents routinely worked over existing finishes and fixtures or removed them. To avoid "wasting" labour and materials, the HDB switched to offering flats that were simply "a bare carcass" - a "shell with cement rendered walls and hollow block walls without plastering" (Wong and Yeh, 1985, page 68). As the official HDB history Housing a Nation reported, "residents ... renovate their flats according to their own tastes and budgets. It helps to keep construction costs low, reduce wastage and minimise the inherent monotony of the standardised floor plans through the resident's personal touch" (Wong and Yeh, 1985, page 68). From the outset, then, the state harnessed individual consumption efforts to the collective consumption of housing such that home improvements worked to subsidise state housing provision (see Baudrillard 2005 [1996], page 24). Under such conditions it is hardly surprising, and was in fact inevitable, that the interior spaces of highrises came to be part of the educative and regulatory efforts of the state. To date, the considerable scholarship on housing provision in Singapore has given limited attention to the ways in which the interiors of homes were shaped. The two notable exceptions, that of Chua (1997) and Castells et al (1990), we have already drawn upon extensively. Theirs is important scholarship_not only for what it tells us about the Singaporean housing process in general, but also the Singapore interior specifically. Each accounts for those interiors by way of quite distinct explanatory frames which, it is useful to dwell upon in relation to our own approach.

Chua's (1997; 1999) sustained interest in the sociology and politics of housing provision in Singapore has included some of the most detailed political and ethnographic accounts. Amongst other things, his work includes rare attention to the detail of how residents lived in their newly acquired highrise flats. For example, Chua observed how individual households were forced to restructure their "symbolic universe" and "cultural practices" upon making the move from more traditional dwelling types to the standardised units of the modernist HDB flats. Such "adjustment", he argued, was "often hindered by restrictive regulations" imposed by the HDB as well as by the 
"values" that were "inscribed" into the design of the standard dwellings themselves (Chua, 1997, pages 6-7). Chua proceeds to give an account of this problem:

"For example, architectural modernism demands that the façade of a block be maintained in uniform colour for visual consistency, reducing residents' freedom to choose the colours of their dwellings. Structural elements that fix the layout of the housing unit itself cannot be tampered with, radically reducing the residents' ability to redeploy the interior spaces provided for them. The restrictions make it difficult for affected households to break away from the monotony of the standardised housing units and transform them into individual 'homes'. As the home is tied to the identity of a household, freedom to individualise will undoubtedly affect the satisfactory adjustments of the occupants" (page 7).

Despite these limits, Chua (1997, pages 90-112) documented in detail one particular type of intervention made by tenants to the standardised flats, this being the cultural adjustments made by ethnically identified occupants (Chinese, Hindu, Malay). For example, he documented the ways in which Chinese residents changed room layouts to create symmetry and accommodate altars; Malays transformed storerooms into prayer rooms; and Hindis partitioned space to ensure religious protocols relating to hygiene. Although opting for the softer notion of "adjustment", Chua's analysis of what residents did to their modernist flats has much in common with the everyday resident 'appropriations' that others have charted in relation to the lived fortunes of European modernism. That said, Chua's observations imply that it was a traditionalised and ethnically identified culture that was the motivating force for residents, interventions in the modernist interiors of Singapore. In Chua's reading of the Singaporean interior, tradition and modernity are set in sharp relief. On the one hand, the imposing modern logics of the highrise produced constraints upon how residents could live. On the other, we are shown how a traditionally determined framework of resources was drawn upon by residents in making limited 'adjustments' to their new homes.

The analysis of Castells et al (1990), in contrast, is suggestive of a wider set of imaginative and material resources at work in the shaping of post-independence Singaporean interiors. Turning specifically to the impact of homeownership, they note that owners would spend often quite substantial additional amounts of money to "rectify and recondition" their flats, "finishing their flats with marble, ceramic, or other tiles, replastering the walls, replacing the doors, upgrading the sanitary fixtures and electrical wiring ... and furnishing their flats" (page 265). Such investment was facilitated in part by credit arrangements available for such purposes, and from early on the pages of Our Home featured advertisements by Credit POSB, a state-supported financial service that offered loans of up to $90 \%$ of the cost of renovation or furnishing projects. Castells et al (1990), drawing on newspaper reports of the time, explain this enthusiastic investment in decoration by reference to the poor quality of the finishes and basic fittings of HDB flats in the 1970s. As they note, "many spent more than what the flats cost to create not just a comfortable home but a luxurious flat" (page 265). Indeed, so extensive was the investment of residents in the interiors of their flats there was concern that the cost of public housing was indirectly being inflated by $10 \%$ to $30 \%$. Furthermore, in the mid-1980s, when a task force was established to inquire into the causes of the economic recession of $1985-86$, it was the collective and individual overinvestment in the housing sector that came under specific scrutiny. According to that task force, by the mid-1980s it was conservatively estimated that an average of $37 \%$ of Singaporean's income was spent on buying a home, housing-related services (such as insurance, maintenance, tax, utilities), and renovation. Not only was this spending deemed excessive, but so too was the aesthetic effect. As Castells et al (1990, page 323) note, because homebuyers did not need to draw from their own savings 
to purchase a flat (drawing instead on CPF savings), they "lavishly spent their savings or even obtained loans to renovate and furnish their flats in an ostentatious manner." So worrying was this excessive expenditure on home improvements that the task force warned that the ability of the CFP to fund old-age pensions might be impaired, sending the nation into financial crisis.

In the final part of this paper we chart a supplementary analytical pathway to those followed by these existing stories of the making of the Singapore interior. In doing so we draw upon Rose's more general analysis of 'interior' realms in modernity. Extending the work of Foucault, Rose has shown how the "private self", as he calls it, is subject to governing by way of a range of medical, sociological, and psychological technologies (Miller and Rose, 1997; Rose, 1989; 1998; Osborne and Rose, 1999). Rose's work is specifically relevant to advanced liberal democracies, in which consumption plays a central role in the making of subjectivity. In such contexts, he argues, power does not simply operate to "dominate, deny and repress", but works through the processes that form and enact subjectivity (1998, page 151). He argues that we can no longer think of clear divisions between "the state" and "private life", suggesting that analysing "the relations between 'the self' and power ... is not a matter of lamenting the ways in which our autonomy is suppressed by the state, but of investigating the ways in which subjectivity has become an essential ... resource for certain strategies ... of regulation" (page 152). In this sense, he exposes how in advanced liberal democracies there is a structure of "governing through the freedom and aspirations of subjects rather than in spite of them" (page 155, original emphasis). As noted, Rose specifically contemplates these arguments in relation to consumption. Consumers, he argues, are constituted as "actors" pursuing a certain "quality of life" or "life-style" by way of "choice in a world of goods" (page 162). The commodity "cast back upon those who purchased it" a certain "glow" that says something of who they are or want to be. "[D]esign, marketing and image construction" play a vital role in this exchange between goods and subjectivity and, most significantly, work to ensure that we are "governed through the choices that we ourselves will make, under the guidance of cultural and cognitive authorities, in the space of regulated freedom" (page 166). In scholarship which directly extends this thinking to the sphere of public housing consumption, Flint (2003) has argued that contemporary social housing clients in the UK are actively being cultivated as consumers of housing. Flint shows how "values, beliefs and sentiments" (what Rose would term "aesthetic elements") prescribe a specific "art" or "grammar" of living (Flint, 2003, page 613; see also Rose, 1989; 1998). This in turn provides the basis for "arm's length" management of social housing populations, such that housing consumption becomes a site for the exercise of "ethopower" - a mechanism for "shaping conduct" more broadly. It is to the shaping of this grammar for living that we now turn.

\section{Interior creativity}

From 1972 through to the late 1989 the HDB published Our Home as a bimonthly magazine that was delivered free to every HDB household in Singapore and was available for purchase at a minimal cost by non-HDB readers (figure 1). ${ }^{(2)}$ The inaugural issue of Our Home magazine begins with a clear statement of purpose:

" 'Our Home' is about you and others in HDB housing estates. You will get to know how much other people are like you, how other residents live, their problems and how to overcome them and about their achievements ... what matters is that we all make that community something to be proud of, a healthy environment for our children .... 'Our Home' can help us all build a better home!" (Editorial Our Home June 1970, page 2).

(2) Circulation began at 161000 (1973) and grew to 440000 (1989). 


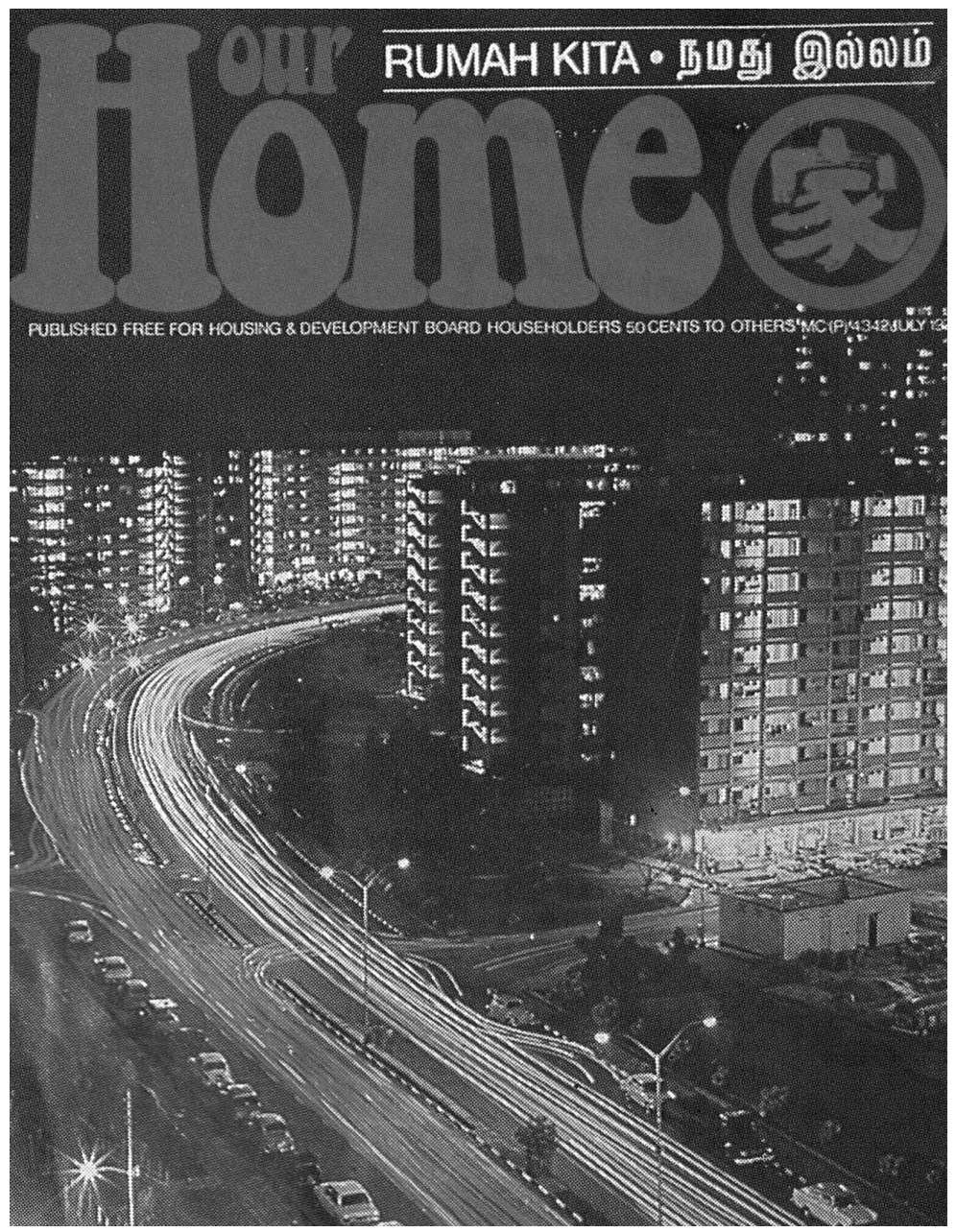

Figure 1. Front cover of first edition of Our Home (1972). C Housing and Development Board, Singapore.

Despite impressive circulation numbers, there is no known study of the readership patterns for this magazine. Anecdotal evidence suggests it is likely that, as time went by, residents thought it increasingly superfluous to the way they lived in their increasingly familiar HDB-provided homes. Be that as it may, the magazine - and, specifically, the articles on interior design we deal with here-offer a unique window onto the fine-grained detail of living in HDB housing, and, specifically, the complex dialogue between HDB aspirations and those of the emerging homeowning democracy which its housing programme aimed to produce.

Among other things, the magazine offered practical advice on how to live "properly" in the new highrise environment, through articles with titles like "Making it a home sweet home" (Our Home 1985, page 40), "Be a good neighbour" (1988, page 11), "More than just a roof" (1976a, page 9). The magazine brought to its readership popular accounts of the new kinds of living problems posed by the high-density, highrise life-ranging from the dangers of littering from a height ("killer litter"), the misuse of shared balcony space, urinating in lifts, to the inappropriate time to hang wet clothes or dripping mops from one's window drying poles. In relation to these problems they suggested more 
"neighbourly" codes of practice, as well as reminding readers of actions and uses that were specifically against the rules. This instructive discourse reminds us that the rehoused Singaporean was seen by the state as a novice with respect to modern housing and living, such that their mode of inhabitation required direct shaping and regulating so that they could maximise the benefit of highrise rehousing. In this sense the HDB was actively constructing and promulgating what Rose (1998, page 38) has usefully called "repertoires of conduct" for highrise living. This educative discourse was underscored by a range of explicit regulations that specified punishable offences, as well as surveillance technologies that ensured compliance.

As noted, part of the HDB's attention in Our Home was dedicated to the way the interior of flats might look. Advice on this appeared routinely in a series of regular articles (often under the thematic heading "Décor") from 1972 to 1982 inclusive and from then on as occasional features. In this subgenre of article the relationship between the making of a modern Singaporean and the cultivation of taste through home-based consumption practices is clearly evident. In Our Home the matter of making the interior of the flat was variously described as "interior décor", "decoration", "design", "home improvement", or simply "renovation". The message about what to do with the interior of one's flat was never communicated in the abstract, or by way of non-HDB homes. All articles featured the efforts of existing HDB residents who had done their interiors themselves, offering photographs of their interiors, and lengthy quotes of these resident's design strategies. The articles are committed to a do-it-yourself (DIY) model of home decoration, although there is a self-conscious conversation with the professionalised field of interior design. For example, one of the earliest of these articles invited readers of Our Home (1973a, pages 20-21) to look inside the interior of a "decorator's flat" in order to see exactly what might happen to an HDB flat with an unlimited budget at the hands of a professional. That Mr Cheung was an interior designer "explains why his home is so beautifully decorated", helped, as he was, by his wife, Sum, a "keen amateur". The featuring of a professional was rare, for the main star of these articles was "The do-it-yourself decorators" (1973b, page 21). This said, the vacillation between amateur and professional interior design values appeared regularly in this subgenre of article. Take, as an example, the article on a flat in Dover Road that began:

"The owners of this three-bedroom flat ... profess they know very little about interior design. And yet [they] have shown that this so-called handicap has in no way prevented them from turning their ordinary flat into a modern and delightful home" (1981a, page 20).

In the next issue the featured flat was owned by another amateur who nonetheless managed to achieve a "professional touch":

"If appearances are anything to go by, one look at Mr Wong's flat will lead you into thinking that you've stepped into an interior decorator's private apartment .... His artistry and flair in doing up his home ... has made it comparable to a professional decorator's" (1981b, page 18).

The article concluded that, despite "ambience", "texture", and "character" being qualities given just the right attention by Mr Wong, to him these were "just vague terms" (page 19). Here, the intermingling of the ideal and real that constitute the modern interior is well illustrated in that individual home-improvement efforts were overwritten with the discourses and visual language of a professionalised field known as 'interior design'. Notably, the Our Home homemakers were also often depicted as men, a feature that warrants attention beyond the scope of this paper. These 'designer' homemakers were called upon to act as models of how other Singaporean homeowners might conduct themselves in relation to their interiors. Thus the HDB resident was equipped not only with ideas of what they too might do in their flat, but also confirmation that one does not 
need to be a professional to create an 'interior design effect'. In this sense, we can see how the HDB sought to cultivate in the modern Singaporean homeowner the figure of the 'interior designer' - a resident who is able to be an engineer of atmosphere (Baudrillard, 2005 [1996], page 25; see also Pennartz, 1999). This framework for delivering design principles placed everyday interpretations and innovations centre stage of the HDB's interior design story, such that modernist design principles were drawn into more ordinary interiors shaped not only by design ideals, but also by the pragmatic limits set by residents' budgets, DIY abilities, and existing furniture.

\section{Colour}

Use of colour was an important part of the advice given to residents through the décor articles in Our Home. Considering the indebtedness of the Singaporean highrise to modernist design principles, it is unsurprising that much advice was about "the dangers of heavy colour" and the practical "sense" of using lighter colours, especially white (1978, pages 21 and 24). As we noted above, within modernism whiteness operated to reveal the true function of architectural form, delivering a transparency and clarity of purpose that was without disguise. This vision of architectural clarity was entangled with wider notions of modernisation, itself expressed through codependent notions of civilisation and cleanliness. For Le Corbusier (1987 [1925], page 188) it is through whiteness that "home is made clean. There are no more dirty, dark corners. Everything is shown as it is" (original emphasis). The link between colonial structures of governance (seeing, monitoring, and controlling colonial subjects) and ideas of cleanliness is now well documented (see as examples Manderson, 1996; Prasha, 2001; Swanson 1977; Thomas, 1990). In the Singapore colonial context, Yeoh (1996, page 215) documented how sanitation "produced a public landscape which was orderly, disciplined, easily policed and amenable to the demands of urban development." In short, a "sanitized city" was at the same time understood to be a "progressive, civilized city". In the context of post-independence Singapore, the emphasis on a clean, orderly city and citizenry remained, but was deployed by a newly empowered local authority in pursuit of its own modernisation agenda. Indeed, the modernist housing programme, with its emphasis on transparency and cleanliness, carried much of the practical and symbolic weight of materialising a progressing and civilising Singapore.

Articles from the first decade of Our Home (the 1970s), in particular, offered advice that was consistent with modernist principles of interior design and its commitment to white and light interiors. White was routinely advocated, as in this observation:

"there is a sense of spaciousness in the flat-contributed in no small way by the white walls" (1976b, page 26).

Or this:

"Walls were all white thus opening out the area. Dark colours would have made the flat look small" (1977b, page 22).

Or this:

"On entering the ... flat ... one is impressed by the spaciousness and simplicity of décor. The living and dining rooms have all-white marble floors and ... [w]alls are white ... [and] white is the dominant colour in the kitchen" (1977a, no page).

Yet there was also ambivalence about going too far with white. For example, one all white flat was found to be "dazzling" but also a little "clinical" and in need of "softening" (1975, page 8). Indeed, it was more a palette of colours generally described as "neutral" - beiges and off-whites - that gained the approval of the HDB. Not only did such colours help make flats look "airy", they did not compromise a "homely" atmosphere. To this approved backdrop residents were encouraged to judiciously add other colours in the form of "highlight", "contrast", or "feature" elements. Mr Lee, for example, was praised 
for his "controlled and cleverly chosen" use of "peacock blue", "flaming red", and "sunshine yellow" in artwork and his creation of "effective spots of colour" through cushions (1975, page 8). Another "modest make-over" was praised for the "nice touches" delivered by way of "paintings" (calendar prints of local artists' work) and "colourful patchwork cushions" (1976b, page 26). Yet another DIY improvement was praised for its effective and economical use of "decorative accents" such as a hand-painted feature brick wall. By the 1980s the commitment to white and light walls was waning and alternative looks (even including heavily ornamented wallpaper) were featured in Our Home alongside those schemes more evidently indebted to modernism. This not only reflected changing interior fashions more generally, but also the new consumer freedoms in relation to colour and style which were afforded by the larger flat sizes.

\section{Clutter}

As noted, the inaugural phase of housing provision by the HDB was undertaken in the name of a diagnosed housing crisis such that many of the earliest HDB provisions were very small one-bedroom $\left(23 \mathrm{~m}^{2}\right)$ or two-bedroom $\left(37 \mathrm{~m}^{2}\right)$ 'emergency' flats. Even the earliest 'improved', 'standard', and 'new generation' flats could be relatively small. Internal space was always at a premium in early HDB offerings, and much of the advice given by way of Our Home was directed at solving the space problem with limited financial outlay. For example, almost all the articles on interior decoration in the first two years of Our Home advised readers to create a simple, low-cost, and uncluttered look in their newly acquired flats. This advice came by way of articles entitled: "Simple and serene" (1974); "Simple and spacious" (1997a, no page), "Original taste yet economical" (1979, page 24); "Simple arrangements" (1978, page 21), "Simple, does it!" (1981c, page 18); "All light and space" (1975, page 8); and "Keeping it simple" (1981a, page 20) (figure 2).

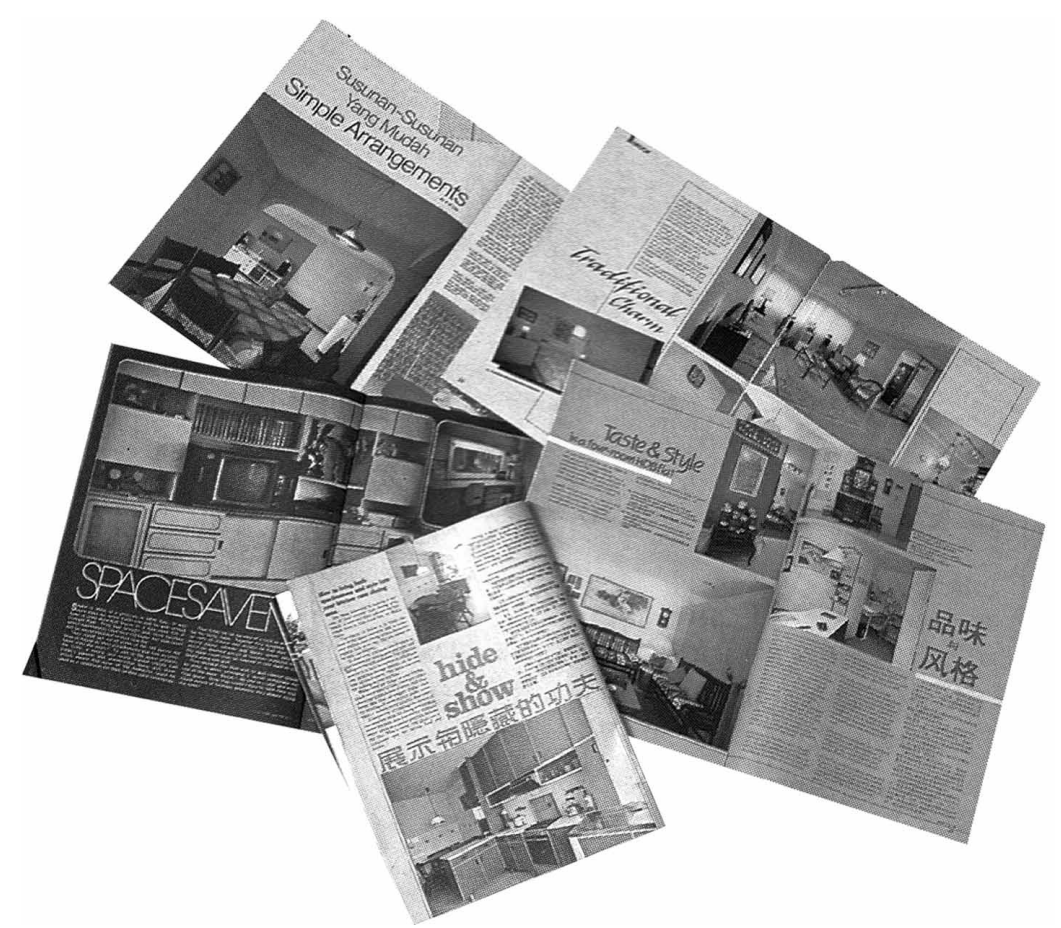

Figure 2. Selection of Our Home decorator articles, showing emphasis on space, simplicity, and storage, as presented in the final issue (Our Home 1989b). (C) Housing and Development Board, Singapore. 
In this context, what to do with 'clutter' was a persistent concern. Indeed, in the advice given about making an appropriate interior for HDB flats it was often assumed that 'design' and 'clutter' were mutually exclusive terms. As Baker (1995, no page) has noted, clutter takes "revenge" on design. What produced 'clutter' varied in the pages of Our Home: furniture of inappropriate size or poorly arranged: inadequate storage spaces, and, of course, too many ornaments. Residents were routinely praised for "resisting ... all temptation to clutter" (1978, page 21) and most of the articles deal in one way or another with this problem. For example, in $1974 \mathrm{Mr}$ Eng Siak Loy shared with others his opinion of clutter:

"I avoid cluttering the flat with bulky and fanciful furniture .... Most people are inclined to do that. However, if they want their flat to be spacious as well as attractive, they can easily create space by choosing the right kind of furniture and arranging it in the right places" (1974, page 38).

Again, in 1981 we visit the home of Mr Chou Kin Loong who also "believes in keeping things simple":

"No ornaments, none of the knick-knacks one usually finds in abundance in so

many other flats. Just simple, clean-cut furnishing which makes the flat more comfortable than trendy, and a good example of wise budgeting" (1981c, page 18). In a similar vein we are introduced to the "elegance" of Mr Tan's flat within which "there is none of the usual ornamental flora and knick knacks that new home owners are wont to decorate their flats with", and where "only functional furniture greets the visitor" (1980a, page 18). And then there were newlyweds, Linda and Derrick Fitzgerald, who simply "don't believe in storing junk" and only kept "what they really need" (1973b, pages $21-22$ ). In these examples the ethos of utility operated as a defence against clutter.

As Cwerner and Metcalfe (2003, page 236) note, the elimination of clutter is not simply produced by the choice not to ornament: it is also a product of how one deals with the "problem" of objects that fall out of frequent use, and which are in need of hiding (storage). Storage, they argue, "is key to understanding how people create order in the home and the world" (page 229). Our Home articles showcased numerous resident-devised innovations for clever storage, including adding storage capacity to existing furniture and fixtures. For example, a very early article advised residents as to how they could "s-t-r-e-t-c-h that space" by using the space above the television for storage, or adding shelves to the back of doors, or fitting drawers below settees (1973c, pages $15-16)$. Another resident advised readers to avoid, admittedly more economical, "readymade furniture". His built-in unit, it was observed, "both acts as a utility and decorative item", and "as [it] has numerous compartments and cupboards, it cuts down on clutter, as everything that was necessary but should be put out of sight was neatly tucked away in the cupboards" (1977b, pages $21-22$ ).

\section{Ornament}

Although obsessed with the 'problem' of clutter, the HDB décor advice did not consistently promote the elimination of ornament. Indeed, ornament was seen to have the power to deliver to domestic interiors a sense of "personal touch" and "atmosphere" in a manner that resonated quite remarkably with the very 19th-century European interior that modernism shunned. Our Home articles encouraged residents to create, in modest and controlled ways, a range of theatrical and phantasmagorical effects. Many of the interiors showcased, including those praised for their use of neutral tones and management of clutter, used ornaments, wall and floor finishes and soft furnishings such as shag-pile rugs, plush carpeting, "big comfy armchairs", gold damask curtains, 
chandeliers, even Victorian-look furniture. Take Dorothy Khoo's flat, which aspired to "have something different from the usual":

"home decorations include carved wood statuettes, ancient vases, Chinese porcelain-most of which are prized collections of older generations. To counter-balance these antiques of the Orient, decoupages, attractive pictures and a gilt-frame mirror adorn the walls" (1979, page 25).

Asian ornaments were commonly featured and articles described flats containing ornamental objects such as a bamboo lamp from Jakarta, a bed in a 'pseudo-Chinese' style, a Namdas Kashmiri rug, a painting of Malay women, Chinese calligraphic hangings, batik paintings, and woodcarving. A good example was the flat of the $\mathrm{Ng}$ family, whose "exquisite display cabinet" presented a "fascinating range of bric-a-brac that have

\section{Does your home need a face $\sim$ lift?}

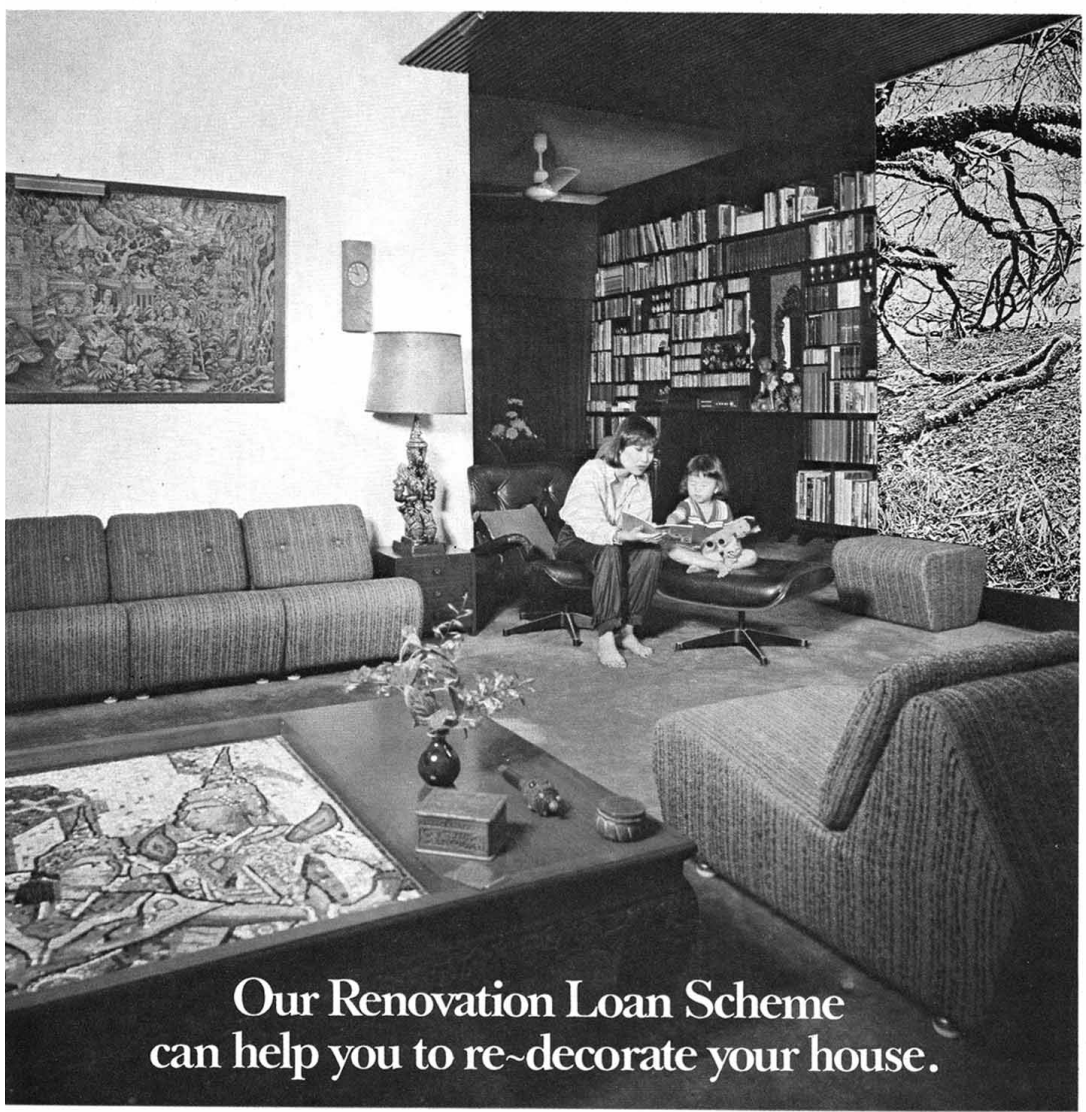

Peeling paint. Scruffy walls, application form, or call in at
chipped linoleum. That's the the Credit POSB Pte. Ltd. Our
kind of home you are ashamed Loans Officer will be only too like to know more about your
to return to. But now with our happy to explain all about our
POSB Home Renovation Loan Scheme. Please
application form.
you can change brochure and an
really turn your house into a
home!
Would you like to know more?
Cut the coupon and we'll send
you further details and an
Write to us at CREDIT POSB PTE. LTD.,CPFBuilding, 9th Floor, Robinson Road, Singapore 1 or call us at 2219522.

Figure 3. Credit POSB 'Renovation Loan Scheme' advertisement (Our Home December 1979). (C) Housing and Development Board, Singapore. 
made it to the [their] flat across continents and oceans", including a giant lobster from Indonesia, a clay dancer from India, and a Taiwanese ornamental umbrella.

Another interior that repeatedly appeared in the pages of Our Home was part of an advertisement campaign by Credit POSB, a state-run bank which offered a Renovation Loan Scheme for residents to redecorate their homes. Again, the interior in this advertisement combines certain features of a modernist aesthetic (white walls most notably) along with a floor-to-ceiling photomontage of a wintry landscape, a mosaic coffee table and lamp with Thai motifs, and a painting in traditional Balinese style (figure 3). It is clear from these examples, that the 'Asian-ness' of these flats is not an expression of some intrinsic cultural trait struggling to find expression against a modernist architecture. Rather, it is a regionally inflected taste culture embedded in the logics of consumption and within which originary cultural traits jostle with the artefacts and atmospheres of other Asias.

Indeed, by the 1980s the way in which these eclectically oriental interiors were described was almost oblivious to any design constraints that might exist by virtue of the architecture. In an article explicitly entitled "The flat where East meets West" (Our Home 1980b, page 12) (figure 4) we are introduced to a householder who has deployed "the best of both worlds". Having "his roots in his past", amateur artist Mr Leong used "oriental themes in his works of art" and chose "oriental ornaments to decorate his flat". But what this article dubbed as the "orientalism" of this décor was set against "Western furnishings": a "comfortable ... sofa and a glass display cabinet". In 1987 this theme was revisited by way of another flat in which there was "a comfortable mix of many cultures": samurai sword, Chinese paintings, Italian dining setting, and "knickknacks from Europe". According to the article, this worldly display was less a product of design than simply an assembly of the various wedding gifts bestowed upon this household by their well-travelled relatives and friends. As the article concludes: "After a hard days work at the office, the Tohs are only too glad to come home to their

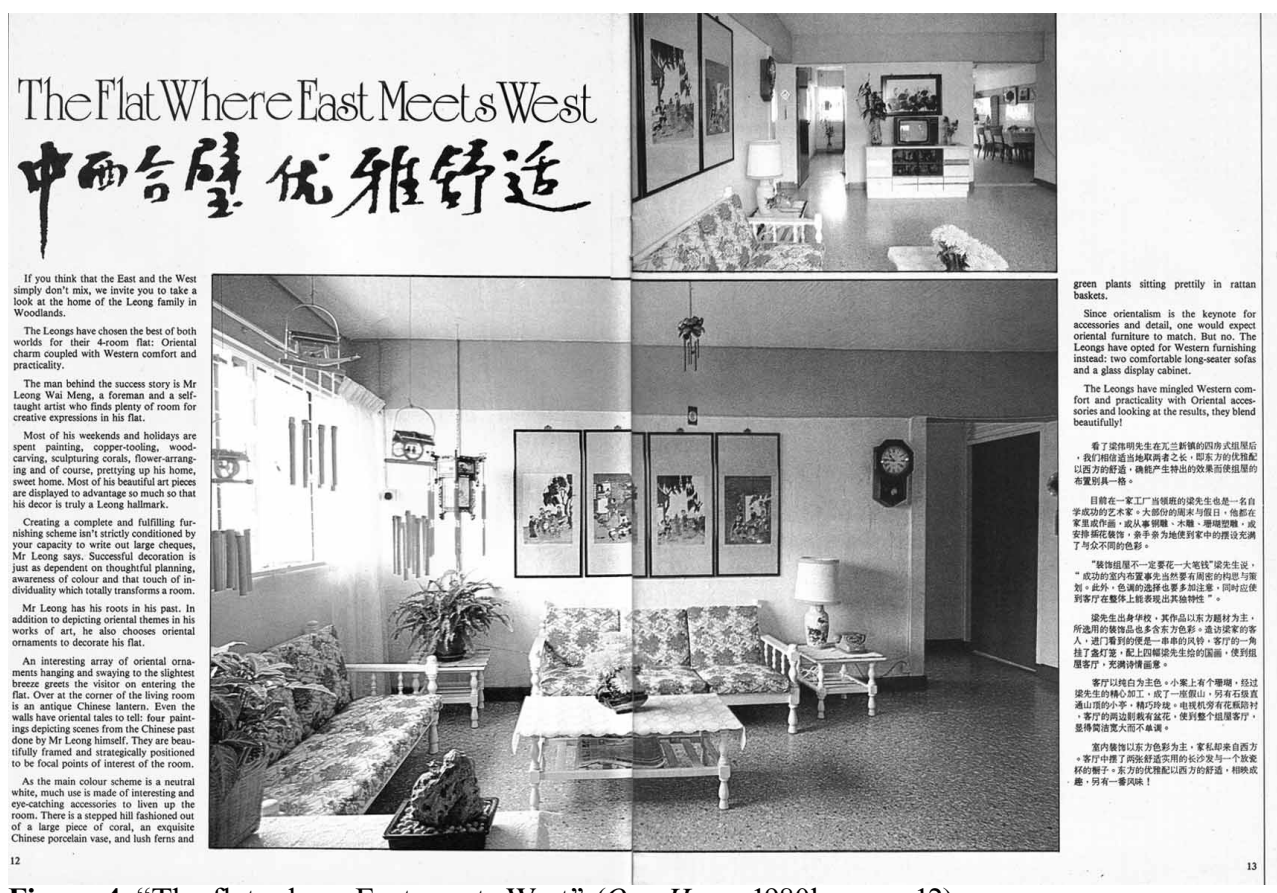

Figure 4. "The flat where East meets West" (Our Home 1980b, page 12).

(C) Housing and Development Board, Singapore. 
comfortable haven with its distinctive mix 'n' match décor of East and West” (1987, page 20).

We have already discussed the problem of storage in the earlier HDB interiors, but storage is a system that is intended to deal with items that fall out of use (either temporarily or permanently). The ornament requires a different structure of housing, for as long as it is on display its visual work in producing atmospheric effect is never done. While Singaporean housing emerged out of a modernism indifferent to display and ornament, the 'space-sensible' display cabinet became an often-featured item in Our Home articles. They make it clear that the Singaporean interior was full of collections and curios of various kinds, all of which needed to be displayed. Mrs Meng, for example, chose to put her "collection of odd pieces of beautiful crockery and pottery" in a "teak sideboard" and a "glass-fronted showcase in blackwood" (1976b, page 26). Mr Wong, whose bespoke furniture we have already seen, elected to use a wall unit that not only hid clutter, but also displayed "all the living room essentials like a TV set, stereo, books and curios" (1977b, page 22). This hybrid system of storage and display was aptly expressed through an article entitled, "Hide and show". The article features a kitchen renovation based on built-in units which could be used, on the one hand, to hide unpleasant-tolook-at kitchen utensils and "odds and ends" but, on the other hand, showcase those items one would "love to show" on an "elegant display shelf" (1980c, page 14).

In the final years of the interior decoration articles in Our Home, the drift toward an ever-more ornamented interior, reminiscent of the very European interiors which modernism deplored, appeared almost complete. In an article entitled "The Continental style" (1985), a home was featured in which, on entering, the visitor was "transported at once to the atmosphere of a house in a small town in Europe" and brought back "to the times of King Louis the fourteenth". The owner, Mr Chan, himself imported European furniture-no doubt servicing a growing local market. In another home featured we encountered the very first interior that was acknowledged not to be the product of the creativity of its owners but the "Italian-style" vision of a "renovation contractor" (1989a, pages 28-29). But perhaps the stylistic destiny of the Singapore interior is best summarised by the last of the décor features to appear in the final edition of Our Home, published in August/September 1989. In a feature entitled "Vast variations" (1989b, pages 29-30), two HDB homes are featured: one based on a "hi-tech" minimalism but incorporating the "folly" of a reproduction London phone booth; the other a heavily ornamented interior that made it "just like a cottage housed in a HDB flat" (figure 5). While modernity's progressive drive seems to be elegantly and effortlessly demonstrated throughout the urban spaces of this city-state-in civic and commercial architecture, public squares and precincts, transportation systems, and service infrastructureshere in the HDB domestic interior we find a more telling, dialectical image of Singapore's modernity in which past and future, East and West, are locked together in an anachronistic embrace.

\section{Managing atmosphere}

Throughout these articles on interior décor the presence of the resident decorator operated to confuse the boundary between state prescription, professionalised design style, and individual expression. In the Our Home articles this was often encapsulated in the positively inflected term "individuality", and elaborated with terms like "creativity", "originality" and "imagination". Many of the featured residents themselves embodied the notion of the "artistic" and "creative" resident, occasionally being professional "designers" of one kind or another, or more usually residents with "amateur" art hobbies who were able to report on their own inexpensive DIY efforts to add creative 


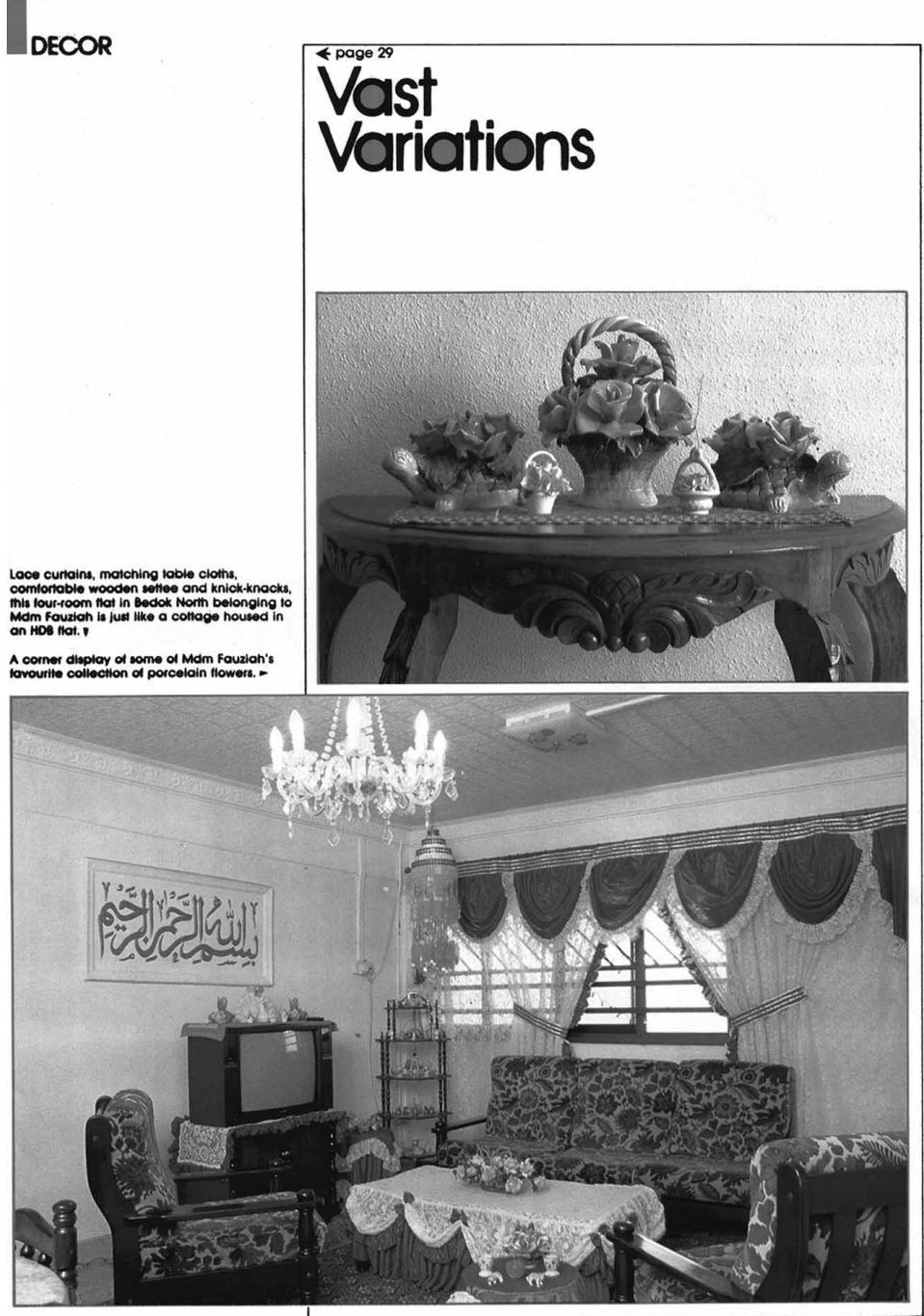

30

Figure 5. "Vast variations" (Our Home 1989b, pages 29-30). (C) Housing and Development Board, Singapore.

touches to their homes (fabric hangings, macramé, mosaic tabletops, paintings, murals, etc). As one article concludes:

"Creating a complete and fulfilling furnishing scheme isn't strictly conditioned by your capacity to write out large cheques .... Successful decoration is just as dependent on thoughtful planning, awareness of colour and that touch of individuality which totally transforms a room" (1980b, page 12$)$.

But the principles of individuality written into the HDB interior rest on a finely balanced ratio of decorating action to atmospheric effect. The exemplary cases that feature in Our Home all represent specified taste incursions that are expressed in consistently modest terms - "touches", "spots" and "accents". These incursions become effective (that is, appropriate) marks of individuality only if they can be shown to have positive effect on the atmosphere of the whole room or flat. The excessive application of too dark or "heavy" a colour, or the excessive display of ornament, in a flat is deemed an 
ill-judged design decision as it compromises the sense of space and openness of the interior.

Furthermore, the encouragment of acts of individuality in relation to HDB interiors was in stark contrast to the kinds of expression allowed in relation to the exterior of the HDB blocks and estates. Resident changes to the external fabric of HDB flats and blocks have always been prohibited. Within HDB publications there is little explicit reflection on the reasons for such prohibitions, and certainly what reflection there is links it directly to practical questions of structural integrity and safety, as opposed to a commitment to a modern aesthetic. Indeed, as the design history of housing provision by the HDB testifies, the HDB quickly moved from a commitment to a purist modernist aesthetic in external design to a range of managed interventions directed at bestowing upon individual estates a unique identity. With the original modernist blocks, this included painting giant murals onto the exterior walls and, later, adding on certain external features, such as prefabricated ornamental panels, distinctive rooflines, and coloured building materials. But for all this external expression, the emergent visual 'diversity' of the HDB fabric remained firmly in the hands of HDB architects, working in conjunction with the Prefabrication Technology Centre. Each time Singaporean homeowners deliberately or incidentally 'expressed' themselves on the exterior of the building this solicited the attention of the HDB, activating existing regulatory regimes or generating alternate design solutions in next-generation estates. For example, in the name of health and safety, a suite of regulations forbade residents from suspending objects from the balcony areas or cultivating plants in open corridor spaces. Similarly, the drying of clothes by way of distinctive bamboo rods extended from the buildings has been managed by the state with increasing intensity over the years. Initially, the very visible rod drying technology was provided for on the rear of blocks but, as time went on, rods were secreted in external recesses designed specifically to hide washing from the exterior of the buildings. Similarly, the visual dilemma produced by a proliferation of individual household television aerials was resolved in the late 1960s by the installation of collective aerials. It would seem that in the Singapore housing system individual expression has its limits, and that limit is contained within the interior.

\section{Conclusion}

The role of the interior in the development of a homeowning democracy in postindependence Singapore reminds us that aesthetic debates about interiors implicate far more than matters of style. The modernist style, although based on and aspiring towards universally applicable design principles, was a situated production - in terms both of its 'ideals' and of its various 'realities'. Linked as it was to more widely conceived reforms, it was readily absorbed into a variety of political and social projects-including that of Singapore's post-independence programme to house a nation. In this practical enactment of the modern style, the interior came into being by way of a complex dialogue between the modernisms evident on drawing boards, those articulated in political rhetoric, those modelled in displays or captured in magaines, those constructed by bureaucracy, and those aspired to by residents. In this sense, the practical making of the modern home in Singapore (as elsewhere) was a multimedia event.

In the post-independence housing programme of Singapore, modernist style meshed with 'disciplinary modernisation' (Wee, 2001) and the 'discipline of the market' (Chua, 1997). In this system aesthetic elements and the look of the interior played a special role within a wider developmental drive, acting both as a source of and as a setting for change. Modernist highrise housing came to be one of the key sites through which the post-independence Singaporean subject was made and made themselves. 
The Singaporean state played a significant role in this process, advising as it did on style and determining physical and aesthetic limits to the extent of creative expression. Yet the novice homeowner enthusiastically played a part too, carefully modelling newly acquired interiors to their own aspirations. Indeed, we hope that this paper has shown how the cultivation of the interior became central to the 'covenant' between people and state. ${ }^{(3)}$

The articles in Our Home do not simply deliver a formula for creating modern interiors: they also furnish residents with the 'taste' equipment necessary to manage the consumption opportunities delivered into their hands by this new form of housing. Our Home sought, then, to develop the "personal capacities" of subjects to be "entrepreneurs of the self" (Flint, 2003, page 614). In this sense, the modern Singaporean interior was a product of the micropolitics of state, subjectivity and built form. In this process of governing the Singaporean interior, it was transformed into a place where individual creative expression was at once cultivated and contained. As the pages of Our Home show, interior creativity needed to be carefully calibrated, such that the aesthetic and economic investments it entailed did not become excessive.

In finally concluding we reflect back again to the HDB Gallery display which gave such prominence to the interior through its staged recreations of Singaporean interiors, old and new. The story there began with a 'premodern' kampung interior, and moved inexorably towards contemporary display flats. The early kampung interior appears utterly out of place and of another time compared with the domestic culture of contemporary Singapore. Indeed, Cogito Image the 'space-branding' firm that designed and installed the display, admitted that its designers had to travel to Malaysia to source the props for this display. It is easy when faced with such evidence (be it the front stage or backstage version of it) to script Singaporean modernism as an alien force, displacing, even erasing, local domestic forms. But our account has sought to counteract both developmentalist stories of modernisation and nostalgic stories of loss. The prescribed modern Singaporean interior does not simply confirm a global story of the spread of modernism. Nor does the practised interior signal a simplistic return of tradition. Rather, the post-independence Singaporean interior embodies an alternative modernity, the alterity of which is not based in any simple way on the (re)emergence of a so-called Asian interior. The evidence from Our Home suggests that the post-independence Singaporean homemaker, encouraged by the state, assembled interiors modelled out of meshing the professional with DIY, the new with the inherited, the modern with the traditional, the global with the local. Indeed, the modern Singaporean interior was often a fantasy creation drawing both on past times and on other places. Within these interiors, any 'Asian-ness' evident was not linked to a residual or resistant cultural presence, but to consumer patterns which mixed and matched objects sourced in various Asian and Southeast Asian localities with local interpretations of European interiors, both modern and traditional. Indeed, the alterity of Singapore's modernism lies firmly in its willingness to accommodate the very type of ornamented and phantasmagorical interior styling with which its European predecessor could not live.

Acknowledgements. We would like to thank Singapore's Housing Development Board for allowing us access to their library and for permission to reproduce images from Our Home. We would also like to thank our anonymous referees and Katie Willis for their most useful comments and Nigel Peake for assisting with images. This research was supported by AHRC Research Grant APN18420.

(3) Yet, the fact that the HDB residents to feature in the pages of Our Home were often male suggests curiuos confusions between the often gendered roles of homeowner, homemaker, and interior designers. These confusions are worthy of further attention in their own right. 


\section{References}

Attfield J, 1989, "Inside pram town: a case study of Harlow house interiors, 1951 - 61", in A View from the Interior: Women and Design Eds J Attfield, P Kirkham (The Women's Press, London) pp $215-238$

Attfield J, 1999, "Bringing modernity home: open plan in the British domestic interior", in At Home: Space, Place and Society Ed. I Cieraad (Syracuse University Press, Syracuse, NY) pp $73-82$

Aynsley J, Berry F, 2005, "Publishing the modern home: magazines and the domestic interior 1870 - 1965" Journal of Design History 18(1) 1 - 5

Baker S, 1995, "To go about noisily: clutter, writing, and design" Émigré 35 unpaginated

Baudrillard J, 2005 The System of Objects (Verso, London); first published in 1996

Baydar Nalbantoglu G, 1997, "Ideal, real and other spatial stories: thoughts on public housing in Singapore" Communal/Plural $5115-130$

Benjamin W, 1973 Charles Baudelaire: A Lyric Poet in the Era of High Capitalism translated by H Zohn (New Left Books, London)

Benjamin W, 1999 The Arcades Project (Belknap Press, Cambridge, MA); first published in 1982

Boudon P, 1979 Le Corbusier's Pessac Revisited (MIT Press, Cambridge, MA)

Buchli V, 1999 An Archaeology of Socialism (Berg, Oxford)

Castells M, Goh L, Kwok R Y-W, 1990 The Shek Kip Mei Syndrome: Economic Development and Public Housing in Hong Kong and Singapore (Pion, London)

Chapman D, Hockey J, 1999, "The ideal home as it is imagined and as it is lived", in Ideal Homes? Social Change and Domestic Life Eds T Chapman, J Hockey (Routledge, London) pp 1-14

Chapman T, 1999, "Stage sets for ideal lives: images of home in contemporary show homes", in Ideal Homes? Social Change and Domestic Life Eds T Chapman, J Hockey (Routledge, London) pp $44-58$

Chua B-H, 1989, "The business of living in Singapore", in Management of Success: The Moulding of Modern Singapore Eds K Singh, P Wheatley (Singapore Institute of Southeast Asian Studies, Singapore) pp $1003-1021$

Chua B-H, 1997 Political Legitimacy and Housing: Stakeholding in Singapore (Routledge, London)

Chua B-H, 2003, "Maintaining housing values under the condition of universal home ownership" Housing Studies 18765 - 780

Clancey G, 2004, "Towards a spatial history of emergency: notes from Singapore", in Beyond Description: Singapore, Space, Historicity Eds R Bishop, J Phillips, W-W-W Yeo (Routledge, London) pp $30-59$

Clarke A J, 2001, "The aesthetics of social aspiration", in Home Possessions Ed. D Miller (Berg, Oxford) pp $23-45$

Cwerner S B, Metcalfe A, 2003, "Storage and clutter: discourses and practices of order in the domestic world" Journal of Design History 16229 - 239

Flint J, 2003, "Housing and ethopolitics: constructing identities of active consumption and responsible community" Economy and Society 32611 - 629

Gullestad M, 1992 The Art of Social Relations: Essays on Culture, Social Action and Everyday Life in Modern Norway (Scandinavian University Press, Oslo)

HDB, 1964 Annual Report Housing Development Board, Singapore

Holland E, 1988, "Schizoanalysis: the postmodern contextualization of psychoanalysis", in Marxism and the Interpretation of Culture Eds C Nelson, L Grossberg (University of Illinois Press, Champaign, IL) pp 405-417

Jacobs J M, 2006, "A geography of big things" Cultural Geographies 131 - 27

Kong L, 2000, "Cultural policy in Singapore: negotiating economic and socio-cultural agendas", Geoforum $31409-424$

Kong L, Yeoh B S A, 1994, "Urban conservation in Singapore: a survey of state policies and popular attitudes" Urban Studies 31247 - 265

Kwek M L, 2004, “Singapore: a skyline of pragmatism”, in Beyond Description: Singapore Space Historicity Eds R Bishop, J Phillips, W-W Yeo (Routledge, London) pp 112 - 124

Lai A H, 1995 The Meanings of Multiethnicity: A Case Study of Ethnicity and Ethnic Relations in Singapore (Oxford University Press, Singapore)

Le Corbusier, 1924 Urbanisme (Crès, Paris)

Le Corbusier, 1987 The Decorative Art of Today translated by J Dunnett (MIT Press, Cambridge, MA); first published 1925

Lim L, 1989, "Social welfare", in Management of Success: The Moulding of Modern Singapore Eds K Singh, P Wheatley (Singapore Institute of Southeast Asian Studies, Singapore) pp $171-200$ 
Lin K-C, Tyabji A, 1991, "Home ownership policy in Singapore: an evaluation" Housing Studies 6 $15-28$

Llewellyn M, 2004, “'Urban village' or 'white house': envisioned spaces, experienced places, and everyday life at Kensal House, London in the 1930s" Environment and Planning D: Society and Space $22229-249$

Loos A, 1997 Ornament and Crime translated by M Mitchell (Ariadne Press, Riverside, CA); first published 1908

Lui T K, 1985, "Overview" in Housing a Nation: 25 Years of Public Housing in Singapore Eds A K Wong, S H K Yeh (Maruzen Asia, Singapore) pp 1-29

Madigan R, Munro M, 1996, "'House beautiful': style and consumption in the home” Sociology $3041-57$

Manderson L, 1996 Sickness and the State: Health and Illness in Colonial Malaya, 1870 - 1940 (Cambridge University Press, Cambridge)

Miller D, 1988, "Appropriating the state on the council estate" Man, New Series 23 353-372

Miller D, 2001a "Behind closed doors", in Home Possessions Ed. D Miller (Berg, Oxford) pp 1 - 19

Miller D, 2001b, "Possessions", in Home Possessions Ed. D Miller (Berg, Oxford) pp 107-121

Miller P, Rose N, 1997, "Mobilising the consumer: assembling the subject of consumption" Theory, Culture and Society $141-36$

Muthesius S, 2005, "Communcation between traders, users and artists: the growth of German language serial publications on domestic interior decoration in the later nineteenth century" Journal of Design History 18(1) 7-20

Osborne T, Rose N, 1999, "Governing cities: notes on the spatialisation of virtue" Environment and Planning D: Society and Space $17737-760$

Our Home 1972, "Editorial", June, page 2

Our Home 1973a, "Interior of a decorator's flat", May/June, pp 20-21

Our Home 1973b, "The do-it-yourself decorators", January/February, pp 21 -22

Our Home 1973c, "Stretch that space", April, pp 15 - 16

Our Home 1974, "Simple and serene", January/February, pp 37 - 38

Our Home 1975, "All light and space", October, pp 8-9

Our Home 1976a, "More than just a roof", December, pp 9-11

Our Home 1976b, "A modest make-over", August, pp 26-27

Our Home 1977a, "Simple and spacious", February, not paginated

Our Home 1977b, "The Wongs' flat at Henderson", June, pp 21 - 22

Our Home 1978, "Simple arrangements", April, pp 21 - 24

Our Home 1979, "Original taste yet economical", June, pp 24-25

Our Home 1980a, "Elegance at its simplest", October, pp 18 - 19

Our Home 1980b, "The flat where East meets West", June, page 12

Our Home 1980c, "Hide and show", April, page 14

Our Home 1981a, "Keeping it simple", April, pp 20-21

Our Home 1981b, "Private paradise with a professional touch", June, pp 18 - 19

Our Home 1981c, "Simple does it!", October, page 18

Our Home 1985, "The Continental Style", October, pp 40-41

Our Home 1987, "A blend of East and West", October, page 20

Our Home 1988, "Be a good neighbour", August, pp $11-12$

Our Home 1989a "La Italia!", April/May, pp 28-29

Our Home 1989b "Vast variations", August, pp 29-30

Pennartz P J, 1999, "The experience of atmosphere", in At Home: An Anthropology of Domestic Space Ed. I Cieraad (Syracuse University Press, Syracuse, NY) pp 95- 106

Perry M, Kong L, Yeoh B, 1997 Singapore: A Developmental City State (John Wiley, Chichester, Sussex)

Prasha V, 2001, "The technology of sanitation in colonial Delhi” Modern Asian Studies 35113 - 155

Reed C, 1996 Not at Home: The Suppression of Domesticity in Modern Art and Architecture (Thames and Hudson, London)

Robinson J, 2006 Ordinary Cities: Between Modernity and Development (Routledge, London)

Rose N, 1989 Governing the Soul: The Shaping of the Private Self (Routledge, London)

Rose N, 1998 Inventing Our Selves: Psychology, Power, and Personhood (Cambridge University Press, Cambridge)

Simmel G, 1950, "The metropolis and mental life", in The Sociology of Georg Simmel translated by K Wolff (Free Press, New York) pp 409-442; first published in 1903 
Sorensen K H, 2002, "Social shaping on the move? On the policy relevance of the social shaping of technology perspective", in Shaping Technology, Guiding Policy: Concepts, Spaces and Tools Eds K N Sorensen, R Williams (Edward Elgar, Cheltenham, Glos) pp 19-36

Sparke P, 2004, "Introduction", in Interior Design and Identity Eds S McKellar, P Sparke (Manchester University Press, Manchester) pp 1-9

Swanson M S, 1977, "The sanitation syndrome: bubonic plague and urban native policy in the Cape colony, 1900 - 1909" Journal of African History 18387 - 410

Tan K J, Loh C T, Tan S A, Lau W C, Kwok K, 1985, "Physical planning and design" in Housing a Nation: 25 Years of Public Housing in Singapore Eds A K Wong, S H K Yeh (Maruzen Asia, Singapore) pp $56-112$

Tan S Y, 1998, Private Ownership of Public Housing in Singapore (Times Academic Press, Singapore)

Thomas N, 1990, "Sanitation and seeing: the creation of state power in early colonial Fiji" Comparative Studies in Society and History $32149-170$

Tolia-Kelly D, 2004, "Locating processes of identification: studying the precipitates of re-memory through artefacts in the British Asian home" Transactions of the Institute of British Geographers, New Series $29314-329$

Tu Y, 1999, "Public home ownership, housing finance and socioeconomic development in Singapore" Review of Urban and Regional Development Studies 11 100 - 113

van Caudenberg A, Heynen H, 2004, "The rational kitchen in the inter-war period in Belgium: discourses and realities" Home Cultures $123-50$

van Herck K, 2005, “'Only where comfort ends does humanity begin': on the 'coldness' of avantguarde architecture in the Weimer period", in Negotiating Domesticity: Spatial Productions of Gender in Modern Architecture Eds H Heynen, G Baydor (Routledge, London) pp 123-144

Wee C W J-L, 2001, "The end of disciplinary modernisation? The Asian economic crisis and the ongoing reinvention of Singapore" Third World Quarterly $22987-1002$

Wigley M, 1995 White Walls, Designer Dresses: The Fashioning of Modern Architecture (MIT Press, Cambridge, MA)

Wong A K, Yeh S H K (Eds), 1985 Housing a Nation: 25 Years of Public Housing in Singapore (Maruzen Asia, Singapore)

Woodham J, 2004, "Design and everyday life at the Britain Can Make It exhibition, 1946" Journal of Architecture $9463-476$

Yeoh B S A, 1996 Contesting Space in Colonial Singapore: Power Relations in the Urban Built Environment (Oxford University Press, Oxford)

Young D J B, 2004, "The material value of colour: the estate agent's tale" Home Cultures 15-22 
Conditions of use. This article may be downloaded from the E\&P website for personal research by members of subscribing organisations. This PDF may not be placed on any website (or other online distribution system) without permission of the publisher. 